\title{
EXERCISE, CHRONOTROPIC AND INOTROPIC CAPACITY IN ATHLETES WITH DIFFERENT TRAINING PROGRAMMES
}

\author{
Sandra Rozenštoka ${ }^{1,2, \#}$ and Andrejs Ërglis ${ }^{3,4}$ \\ ${ }^{1}$ Sports Laboratory, Collaboration Centre of International Federation of Sports Medicine, 363 Brīvības Av., Rīga, LV-1024, LATVIA \\ 2 Doctoral Study Department, Rīga Stradinš University, 16 Dzirciema Str., Rīga, LV-1007, LATVIA \\ ${ }^{3}$ Latvian Centre of Cardiology, Pauls Stradinš Clinical University Hospital, 13 Pilsoṇu Str., Rīga, LV-1002, LATVIA \\ 4 University of Latvia, 19 Raina Blvd., Rīga, LV-1586, LATVIA \\ \# Corresponding author, sandra@sportlab.Iv
}

Contributed by Andrejs Ërglis

\begin{abstract}
Amateur sport has significant influence on peoples' physical activity and affects the prevalence of non-communicable diseases. The population of competing amateur athletes has not been sufficiently studied, and there is a huge gap between functional results of untrained individuals and professional athletes. The aim of the study was to evaluate the exercise capacity and chronotropic, inotropic capacity in amateur athletes with different training programmes, as assessed by cardiopulmonary exercise testing. In a longitudinal prospective study, 600 amateur athletes who performed high dynamic load sports, according to the Mitchell Classification of Sports, were assessed. The individuals underwent standard maximum cardiopulmonary exercise testing on the ISO certified Master screen CPX system. The exercise capacity was dependent on the training programme organisation, regularity and duration, but it was not dependent on age. During maximum work-rate, the functional parameters of the cardiorespiratory system and inotropic capacity were significantly dependent on duration of the training programme. Chronotropic and inotropic capacity, as well as cardiorespiratory adaptation were significantly higher for competing amateur athletes of both genders than for untrained individuals. The study showed that amateur athletes with a training programme 300 minutes per week had higher exercise capacity, which was based on the individually suitable training programme, and higher aerobic and anaerobic capacity. Regular pre-competition medical assessment of amateur athletes can be used to objectively evaluate their health condition, adaptation, cardiac risk and make changes in the athletes' training programme.
\end{abstract}

Key words: exercise capacity, inotropic, chronotropic, adaptation, amateur athlete.

\section{INTRODUCTION}

Non-communicable preventable diseases such as cardiovascular disease, respiratory disease, diabetes, cancer and others cause death of more than 14 million people per year before the age of 70 (Anonymous, 2015). Physical activity is one of the main factors that affect the prevalence of noncommunicable diseases. The goal of the World Health Organisation's (WHO) Global Action Plan for the Prevention and Control of Noncommunicable Diseases in 2013-2020 is to increase people's physical activity and reduce the number of physically inactive people by $10 \%$ till 2025 (Anonymous, 2015). The WHO definition states: physical activity is any activity or body movement during work, leisure and sporting time which increases the production of energy by skeletal muscles (Anonymous, 2018). It is important to recognise the distinction between physical activity and physical exercise. Physical exercise is defined as a subcategory of physical activity (Anonymous, 2018). It is equally important to identify a physically active individual, a physically exercised individual, and an athlete. In this study, the functional evaluation of the body was done for athletes defined as persons who participate in sports and take part in official sports competitions (Anonymous, 2002). 
The goal of the WHO will be accomplished if peoples' motivation to be active increases. Amateur sports could have a significant impact on achieving this goal. Amateur sports also have an important social function when all family members can be involved in different physical exercises. However, amateur sports differ from professional sports. Amateur sports involve members of all age groups, are rarely scheduled and often involve an irregular training programme, without the advice of a sports medicine doctor and a sports trainer, and are merely participation in competitions (Mayolas et al., 2017). The population of competing amateur athletes has not been sufficiently studied, and there is a huge gap between functional results of untrained individuals and professional athletes.

The WHO Global Recommendations for Physical Activity for Health are general and determine the following exercise duration for adults: 75-150 minutes of physical activity per week with additional health benefits if physical activity time increases up to 300 minutes per week (Anonymous, 2010). The ability of athletes to do regular and intensive training is supported by adequate neural, physiological and morphological adaptation. The adaptation to the physical exercise depends on health condition, training programme and type of sport (Predel, 2014).

If a training programme does not bring the expected result - improvement of athletes' health and physical working capacity - it can lead to various health risks including overload and cardiovascular risk (Skalik, 2015). Inadequate heart capacity and functional response to physical exercise can significantly increase the risk of an acute cardiovascular event. The health condition and benefits of physical exercise for each individual should be periodically estimated subjectively and objectively (Predel, 2014). For reduction of cardiovascular and mortality risks, the European Society of Cardiology recommends evidence-based pre-competition medical assessment of athletes (Mont et al., 2016). Heart chronotropic and inotropic capacity connected with different training programmes of amateur athletes has not been sufficiently studied. The aim of the study was to evaluate the exercise capacity and chronotropic, inotropic capacity in amateur athletes with different training programmes, as assessed by cardiopulmonary exercise testing.

\section{MATERIALS AND METHODS}

In a longitudinal prospective study, 200 female and 400 male competing amateur athletes aged 20-39 years were assessed. All involved amateur athletes had no cardiorespiratory disease and they performed high dynamic load sports, according to the Mitchell Classification of Sports: cycling, rowing, running, cross-country-skiing, swimming, basketball, soccer, ice-hockey and triathlon (Mitchell et al., 1994).

All of the participants were divided into groups by age, gender and duration of training programme under or above 300 training minutes per week by the WHO Global Recommen- dations for Physical Activity for Health (Anonymous, 2010):

- Participants aged 20-29: Group $1-100$ males with $\leq 300$ training minutes per week; Group 2 - 100 males with > 300 training minutes per week; Group 3 - 50 females with $\leq 300$ training minutes per week; and Group $4-50$ females with $>300$ training minutes per week;

- Participants aged 30-39: Group 5- 100 males with $\leq 300$ training minutes per week; Group 6 - 100 males with > 300 training minutes per week; Group 7 - 50 females with $\leq 300$ training minutes per week; and Group $8-50$ females with $>300$ training minutes per week.

The following anthropometry measurements were made: weight, height, and body mass index. The age to restart trainings, training programmes, coaches' guidance, regularity and duration per week were assessed. The cardiopulmonary exercise testing was performed on the International Organisation for Standardisation certified Master Screen Cardiopulmonary Exercise Testing System using the testing protocol with four phases: rest -1 minute; reference -1 minute 50 Watts (W) work-rate; exercise - stepping increased work-rate by $15 \mathrm{~W} / \mathrm{min}$ till maximum work-rate; recovery -2 minutes decreased work-rate of 50-25 W and 4 minutes passive recovery. The Master Screen Cardiopulmonary Exercise Testing system was used to record the parameters analysed in the study: relative work-rate, heart rate (HR), systolic and diastolic blood pressure, stroke volume, cardiac output, oxygen uptake, metabolic equivalent, also aerobic and anaerobic thresholds, which were based on the respiratory exchange ratio and ventilation equivalent.

The predicted maximum HR was calculated by using the age-predicted maximum HR formula defined for healthy populations by Astrand 220 minus age formula (Dobre et al., 2013). Maximum HR was observed in the last minute of the exercise testing. The Chronotropic index (CI) was used as the index of maximum predicted HR reserve, also for the estimation of the chronotropic capacity, cardiovascular (ischemia) risk and additional diagnostic or necessary changes in the training programme (Dobre et al., 2013). $\mathrm{CI}=($ maximum $\mathrm{HR}-$ rest $\mathrm{HR}) /((220-$ age $)-$ rest $\mathrm{HR}))^{*} 100$. If CI was less than $80 \%$, it was estimated as abnormal (Azarbal et al., 2004). The exercise capacity, ST changes in electrocardiography (ECG) and Robinson index (RI) were used for the estimation of oxygen consumption of the myocardium and as the diagnostic criteria of coronary artery disease (Mintale and Erglis, 2008). RI = maximum $\mathrm{HR}^{*}$ maximum systolic blood pressure/100.

The exercise capacity and chronotropic, inotropic capacity were expressed by the physical working capacity of the body, the cardiac response to the defined physical exercises, the maximum oxygen uptake, aerobic and anaerobic thresholds, as well as recovery after the physical exercises and other indicators. 
SPSS software, version 22.0 (IBM SPSS, Corp., Armonk, NY) was used for the data statistical analysis. Categorical variables were described as frequencies and percentages. Normally distributed continuous variables were described as means and standard deviations (SD), or as medians and ranges in the case of non-normal distribution. Comparisons between groups of participants according to training programme and gender were performed using the Student t-test or Mann-Whitney test, according to the distribution of variables. Categorical variables were compared with Pearson Chi-square or Fisher exact test. Significance was considered as $p<0.05$.

All of the participants of the study gave signed consent. The study was approved by the Ethics Committee of Riga Stradiňš University.

\section{RESULTS}

600 adult amateur athletes were assessed. The body mass index of the participants was within normal range, except in Group 5 (Table 1). The average duration of an uninterrupted training period was approximately 4-5 years for both gender amateur athletes, except in Group 2-11-12 years. The regularity of the training programme was significantly high: more than $73.0 \%$ of both gender amateur athletes with $\leq$ 300 training minutes per week and more than $94.0 \%$ with $>300$ training minutes per week had a regular training programme $(p<0.01)$. Coach guidance was prevalent in athlete groups with $>300$ training minutes per week (Table 1).

The exercise capacity and maximum relative work-rate significantly depended on the duration of training programme, but it was not dependent on age (Table 2). The difference in exercise capacity was based on significantly higher aerobic and anaerobic capacity of athletes with 300 training minutes per week $(p<0.01)$. The aerobic threshold work-rate for Group 1 was in $113 \pm 29 \mathrm{~W}$, Group $2-149 \pm 34 \mathrm{~W}$, Group $3-80 \pm 29 \mathrm{~W}$, Group $4-96 \pm 26 \mathrm{~W}$, Group $5-119 \pm$ $31 \mathrm{~W}$, Group $6-137 \pm 33 \mathrm{~W}$, Group $7-78 \pm 19 \mathrm{~W}$ and Group $8-101 \pm 27 \mathrm{~W}$. Anaerobic threshold work-rate for Group 1 was in $191 \pm 34 \mathrm{~W}$, Group $2-254 \pm 37 \mathrm{~W}$, Group $3-137 \pm 35 \mathrm{~W}$, Group $4-179 \pm 37 \mathrm{~W}$, Group $5-206 \pm 41$ $\mathrm{W}$, Group $6-230 \pm 43 \mathrm{~W}$, Group $7-135 \pm 28 \mathrm{~W}$ and Group $8-173 \pm 37 \mathrm{~W}$.

During maximum work-rate the functional parameters of the cardiorespiratory system and the inotropic capacity were significantly dependent on the duration of training programme: higher stroke volume, cardiac output, maximum relative oxygen uptake, metabolic equivalent and lower diastolic blood pressure (Table 2). The chronotropic index was in the normal range for all research groups. However, there were some individuals with an abnormal chronotropic index less than $80 \%$ (Azarbal et al., 2004) and increased cardiovascular risk: Group 1-14 (14.0\%), Group 2 - 12 (12.0\%), Group $3-6(12.0 \%)$, Group $4-6(12.0 \%)$, Group $5-4$ $(4.0 \%)$ and Group $6-5(5.0 \%)$, Group $7-10(20.0 \%)$ and Group $8-3(6.0 \%)$.

Table 1. Characteristics of the groups, by age, gender and duration of the training programme

\begin{tabular}{|c|c|c|c|c|c|c|}
\hline \multirow{3}{*}{ Characteristics } & \multicolumn{6}{|c|}{ 20-29 years old athletes } \\
\hline & \multicolumn{3}{|c|}{ Men } & \multicolumn{3}{|c|}{ Women } \\
\hline & $\begin{array}{c}\text { Group 1, } \\
\mathrm{n}=100\end{array}$ & $\begin{array}{c}\text { Group 2, } \\
\mathrm{n}=100\end{array}$ & $p$ & $\begin{array}{c}\text { Group 3, } \\
\mathrm{n}=50\end{array}$ & $\begin{array}{c}\text { Group 4, } \\
\mathrm{n}=50\end{array}$ & $p$ \\
\hline Age, years & $25.23 \pm 2.69$ & $23.97 \pm 2.74$ & 0.01 & $24.92 \pm 2.05$ & $25.04 \pm 2.25$ & 0.99 \\
\hline Height, $\mathrm{cm}$ & $183.44 \pm 9.73$ & $185.29 \pm 8.12$ & 0.36 & $170.30 \pm 5.84$ & $170.02 \pm 6.03$ & 1.00 \\
\hline Weight, kg & $82.59 \pm 13.78$ & $83.40 \pm 11.54$ & 0.96 & $64.26 \pm 8.41$ & $63.39 \pm 8.50$ & 0.97 \\
\hline Body mass index, $\mathrm{kg} / \mathrm{m}^{2}$ & $24.45 \pm 2.80$ & $24.22 \pm 2.28$ & 0.92 & $22.15 \pm 2.67$ & $21.89 \pm 2.41$ & 0.96 \\
\hline Age to restart trainings, years & $20.50[12.25 ; 5.00]$ & $12.50[6.00 ; 21.00]$ & $<0.01$ & $22.00[20.00 ; 23.00]$ & $21.00[13.00 ; 23.00]$ & 0.09 \\
\hline Coach guidance & $33(33.0)$ & $57(57.0)$ & $<0.01$ & $8(16.0)$ & $17(34.0)$ & 0.04 \\
\hline Duration of training, min/week & $240[124 ; 293]$ & $540[370 ; 743]$ & $<0.01$ & $154[98 ; 185]$ & $360[360 ; 458]$ & $<0.01$ \\
\hline \multirow[t]{2}{*}{ Characteristics } & \multicolumn{6}{|c|}{ 30-39 years old athletes } \\
\hline & \multicolumn{3}{|c|}{ Men } & \multicolumn{3}{|c|}{ Women } \\
\hline Age, years & $34.46 \pm 2.77$ & $33.89 \pm 2.75$ & 0.46 & $34.22 \pm 2.40$ & $33.22 \pm 2.38$ & 0.14 \\
\hline Height, cm & $181.95 \pm 6.17$ & $181.11 \pm 6.20$ & 0.78 & $169.83 \pm 5.74$ & $169.51 \pm 5.40$ & 0.58 \\
\hline Weight, kg & $88.01 \pm 11.63$ & $81.40 \pm 11.45$ & $<0.01$ & $66.88 \pm 8.54$ & $64.81 \pm 9.19$ & 0.68 \\
\hline Body mass index, $\mathrm{kg} / \mathrm{m}^{2}$ & $26.58 \pm 3.22$ & $24.78 \pm 2.94$ & $<0.01$ & $23.19 \pm 2.85$ & $22.52 \pm 2.69$ & 0.58 \\
\hline Age to restart trainings, years & $30.00[26.25 ; 33.00]$ & $29.00[25.25 ; 32.75]$ & 0.39 & $31.00[27.75 ; 34.00]$ & $29.00[23.75 ; 31.00]$ & $<0.01$ \\
\hline Coach guidance & $9(9.0)$ & $24(24.0)$ & $<.01$ & $6(12.0)$ & $9(18.0)$ & 0.40 \\
\hline Duration of training, min/week & $155[210 ; 210]$ & $383[360 ; 600]$ & $<0.01$ & $150[60 ; 180]$ & $360[326 ; 376]$ & $<0.01$ \\
\hline
\end{tabular}

$\mathrm{n}$, number of participants

Data are presented as mean $\pm \mathrm{SD}$, Standard Deviation or $\mathrm{n}(\%)$, or median [minimum; maximum] value unless stated otherwise. 


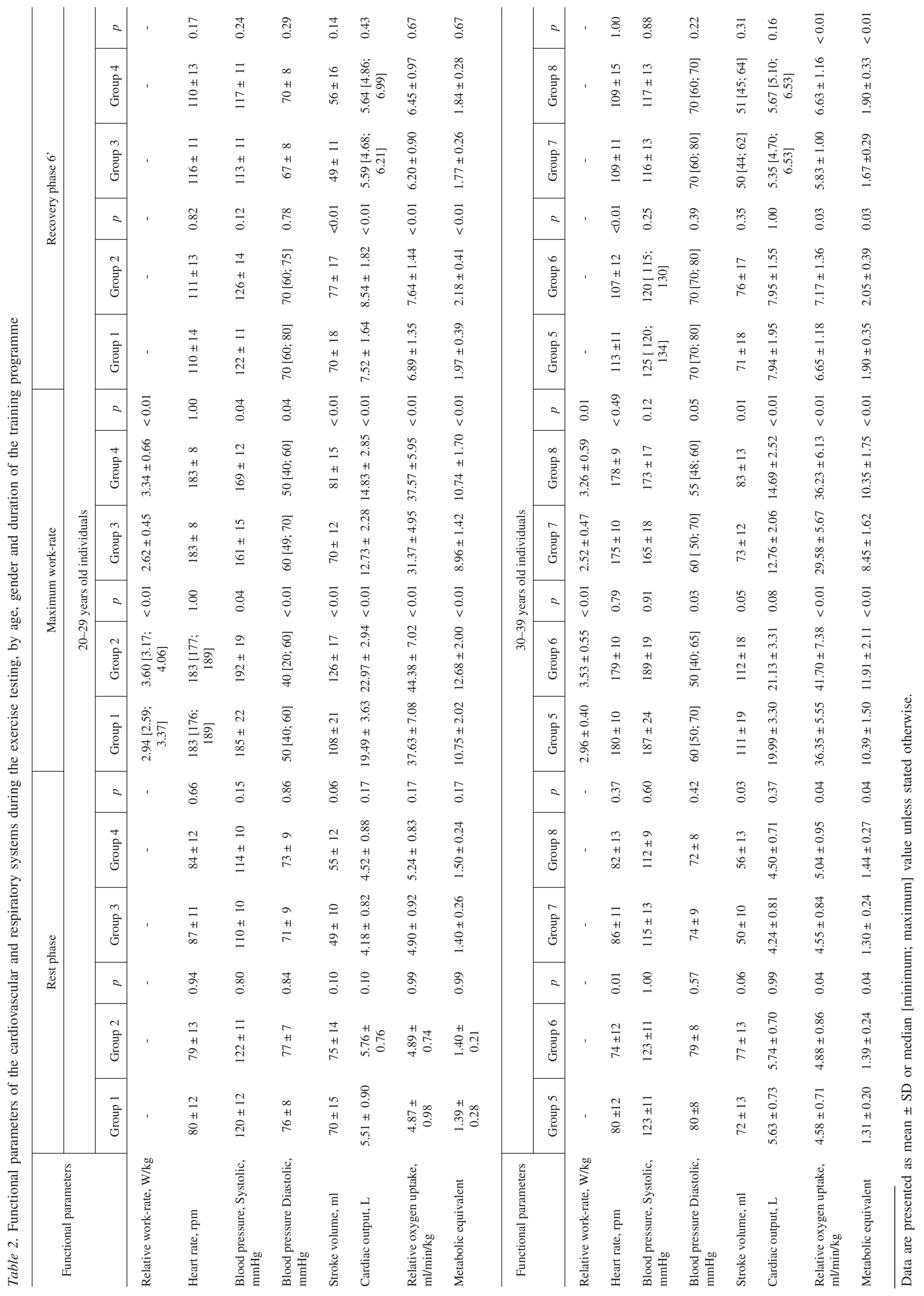


During the exercise testing, normal sinus rhythm was recorded in ECG for all of the athletes. In the ECG, various changes without significant differences between the groups were observed: incomplete right bundle branch block with a normal duration of the QRS complex was found in 86 $(21.5 \%)$ male and in $18(9.0 \%)$ female athletes; nonspecific ST segment and $\mathrm{T}$ wave changes during the exercise in 89 $(22.3 \%)$ male and in $75(37.5 \%)$ female athletes; and ischemic changes during the exercise in $9(2.3 \%)$ male and $6(3.0 \%)$ female athletes. All amateur athletes with ischemic changes during the exercise in ECG were sent to receive additional cardiac diagnostics.

The reasons for interruption of cardiopulmonary exercise testing did not show statistically significant differences between the groups and were excluded for further study. The most frequent reason in male athletes was lower limb muscle fatigue with difficulties in further pedalling in definite cadence: Group $1-46$ (46.0\%), Group 2 - 41 (41.0\%), Group 5 - 34 (34.0\%) and Group 6-38 (38.0\%); in female amateur athletes the main reason was shortness of breath: Group 3 - 20 (40.0\%), Group 4 - 21 (42.0\%), Group 7 - 18 $(36.0 \%)$ and Group $8-24(48.0 \%)$.

Functional cardiopulmonary and muscular recovery without significant differences between the groups was prolonged for the majority of both gender athletes. Adequate recovery was observed merely in $71(17.8 \%)$ male and $31(15.5 \%)$ female amateur athletes (Table 3).

\section{DISCUSSION}

Sports performance requires adequate physiological response and cardiorespiratory adaptation (Rozenstoka et al., 2010). Differences in training programme organisation, regularity and duration affect exercise capacity and maximum relative work-rate. In the study, competing male amateur athletes reached less maximum relative work-rate than professional male athletes. This difference was due to lower functionality of the body systems as well as lower resistance to fatigue, and functional and morphological changes in the heart (Brugada and Benito, 2006). An effect of age on exercise capacity was not found for athletes of either gender as previously described (Beaumont et al., 2018). However, we consider that a regular training programme can provide better and more valuable functionality and morphological changes in the cardiopulmonary system, as well as reduced the risk of cardiac diseases and mortality in competing athletes (Corrado et al., 2006).

It was found that during resting the stroke volume did not depend on age and duration of training programme, except in Groups 7 and 8. Stroke volume depends on gender, body composition, previous sports anamnesis, size of the heart, sympathetic stimulation of the heart, its contractility and other factors (Wheatley et al., 2014). The stroke volume was 70-77 $\mathrm{ml}$ for male athletes who compete, which was significantly higher than the 50-60 ml stroke volume of an untrained male mentioned in the literature (Utomi et al., 2013). During the testing, the stroke volume of amateur athletes was lower than in professional athletes (160-180 ml), and higher than in untrained persons $(100 \mathrm{ml})$ (Degens et al., 2019). The study showed that during the exercise, the stroke volume depended on duration of the training programme. Male athletes in Group 2 reached $126 \pm 17 \mathrm{ml}$ stroke volume and $112 \pm 18 \mathrm{ml}$ in Group 6. Female amateur athletes who compete reached a significantly lower stroke volume during the exercise: $81-83 \mathrm{ml}$ compared to $125 \mathrm{ml}$ stroke volume in professional female athletes (Ferguson et al., 2001).

In the study physical exercise testing did not provoke heart rhythm disorders in the participants. The ECG of 104 $(17.3 \%)$ athletes showed an incomplete right bundle branch

Table 3. Results of final testing of groups, by age, gender and duration of the training programme

\begin{tabular}{|c|c|c|c|c|c|c|}
\hline \multirow{3}{*}{ Characteristics } & \multicolumn{6}{|c|}{ 20-29 years } \\
\hline & \multicolumn{3}{|c|}{ Men } & \multicolumn{3}{|c|}{ Women } \\
\hline & $\begin{array}{c}\text { Group 1, } \\
\mathrm{n}=100\end{array}$ & $\begin{array}{c}\text { Group 2, } \\
\mathrm{n}=100\end{array}$ & $p$ & $\begin{array}{c}\text { Group 3, } \\
\mathrm{n}=50\end{array}$ & $\begin{array}{c}\text { Group 4, } \\
\mathrm{n}=50\end{array}$ & $p$ \\
\hline Chronotropic index & $88.93 \pm 9.62$ & $88.55 \pm 8.34$ & 0.99 & $88.77 \pm 7.00$ & $89.02 \pm 6.88$ & 0.89 \\
\hline Robinson index & $336 \pm 40$ & $349 \pm 36$ & 0.95 & $294 \pm 31$ & $308 \pm 28$ & 0.12 \\
\hline Individuals with good recovery & $21(21.0)$ & $14(14.0)$ & 0.35 & $3(6.0)$ & $8(16.0)$ & 0.09 \\
\hline Individuals with decreased adaptation to the physical exercise & $79(79.0)$ & $86(86.0)$ & 0.36 & $48(96.0)$ & $42(84.0)$ & 0.07 \\
\hline \multirow{3}{*}{ Characteristics } & \multicolumn{6}{|c|}{$30-39$ years } \\
\hline & \multicolumn{3}{|c|}{ Men } & \multicolumn{3}{|c|}{ Women } \\
\hline & $\begin{array}{c}\text { Group } 5 \\
\mathrm{n}=100\end{array}$ & $\begin{array}{c}\text { Group } 6 \\
\mathrm{n}=100\end{array}$ & $p$ & $\begin{array}{c}\text { Group 7, } \\
\mathrm{n}=50\end{array}$ & $\begin{array}{c}\text { Group } 8 \\
n=50\end{array}$ & $p$ \\
\hline Chronotropic index & $91.18 \pm 9.98$ & $93.90 \pm 8.65$ & 0.68 & $89.38 \pm 9.39$ & $91.61 \pm 8.28$ & 0.19 \\
\hline Individuals with good recovery & $9(9.0)$ & $27(27.0)$ & $<0.01$ & $8(16.0)$ & $12(24.0)$ & 0.37 \\
\hline Individuals with decreased adaptation to the physical exercise & $95(95.0)$ & $74(74.0)$ & $<0.01$ & $43(86.0)$ & $39(78.0)$ & 0.18 \\
\hline
\end{tabular}

n, number of participants

Data are presented as mean $\pm \mathrm{SD}$, Standard Deviation or $\mathrm{n}(\%)$ unless stated otherwise. 
block with a normal duration of the QRS complex, which for most individuals does not give any clinical evidence of structural heart disease (Le et al., 2005). During precompetition medical assessment for professional and amateur athletes, it is important to look for heart rhythm disorders that could increase the risk of acute cardiac event or sudden cardiac death (Brugada and Benito, 2006).

It is known that a regular training programme and participation in sports competitions can increase average relative risk of sudden cardiac death by 2.8 times compared to untrained individuals (Corrado et al., 2006; Anonymous, 2009). The ECG findings can show underlying cardiovascular diseases and cardiovascular risks. An increased work-rate, HR and stroke volume combined with a shortened diastolic time can lead to reduced coronary perfusion, which can result in ST segment and/or T wave changes in ECG (Mintale and Erglis, 2008). It is important to recognise amateur athletes with nonspecific ST segment and T wave changes in precompetition medical assessment, especially with ischemic ST depression 2-3 mm 0.06-0.08 from the J-point in the ECG, to determine when exercise testing has to be limited (Bodegard et al, 2005). These amateur athletes should undergo additional cardiac diagnostics to exclude cardiomyopathy and anomalies of coronary arteries, in order to start treatment and an individually suitable training programme with restrictions (Corrado et al., 2006). We support the European Society of Cardiology Recommendations that all athletes should be checked with a pre-competition medical assessment.

The functionality of the respiratory system can be described by the relative maximum oxygen uptake, which has an upper limit for a person's current health condition (Mayolas et al., 2017). In the study it was confirmed that oxygen uptake is significantly affected by gender, age, and duration of the training programme. Male athletes in Group 2 had $17.9 \%$ higher oxygen uptake than athletes (Group 1). Oxygen uptake, which is the best predictor of cardiac and mortality risks, is limited by cardiac output, its fractional distribution in the involved muscles, oxygen saturation of arterial blood and oxygen utilisation of muscle cells (Aspenes et al., 2011). Male athletes in Group 1 reached a relative maximum oxygen uptake of $37.63 \pm 7.08 \mathrm{ml} / \mathrm{min} / \mathrm{kg}$, whereas in Group 2 they had a $17.9 \%$ higher relative maximum oxygen uptake. However, maximum relative oxygen uptake is significantly higher in professional male athletes (65-76 $\mathrm{ml} / \mathrm{min} / \mathrm{kg}$ ) (Utomi et al., 2013). Female athletes in Group 4 had $16.5 \%$ higher oxygen uptake than female athletes in Group 3. The adequacy of a training programme is an important factor for all amateur athletes who compete. High oxygen uptake provides an important preventive function of different diseases and decreases cardiovascular risk (Aspenes et al., 2011).

During a regular and intense training programme, recovery is essential for successful sports performance (Rozenstoka et al., 2010). Recovery data can help evaluate the adequacy of a training programme and adaptation to physical exercise. In the study, more than $73 \%$ of all competing amateur athletes displayed a prolonged recovery and reduced adaptation to the physical exercise. However, the results of male amateur athletes (Group 1 and 2) confirmed that athletes who received coach guidance and had a more regular and intensive training programme showed better adaptation to physical exercise and faster recovery.

Individual characteristics should be taken into consideration when planning a training programme for an amateur athlete, which can protect a competing amateur athlete from overtraining, reduce overload and decrease health risks. Regular pre-competition medical assessment of an amateur athlete can help a physician to objectively evaluate the health condition, cardiac risk, as well as make changes in an athlete's training programme.

Chronotropic and inotropic capacity and cardiorespiratory adaptation were significantly better in amateur athletes of both genders than in untrained individuals. The study showed that amateur athletes with a training programme 300 minutes per week had a higher exercise capacity, which was based on an individually suitable training programme, and higher aerobic and anaerobic capacity. The health condition, adaptation, inotropic and chronotropic capacity and exercise capacity of amateur athletes should be screened with pre-competition medical assessment, as is done for professional athletes.

\section{ACKNOWLEDGEMENTS}

The authors express their gratitude to the Sports Laboratory and Latvian Cardiology Centre for their support in conducting the research.

\section{DECLARATION OF CONFLICTING INTERESTS}

The authors declared no potential conflict of interest with respect to the research, authorship and publication of this article.

\section{REFERENCES}

Anonymous (2002). LR Sporta likums [LR Sports Law]. LR Saeima. Latvijas Vēstnesis, 165, 2740. Available at: http://likumi.lv/doc.php?id=68294 (accessed 10.01.2020) (in Latvian).

Anonymous (2009). The International Olympic Committee (IOC) Consensus Statement on Periodic Health Evaluation of Elite Athletes. J. Athl. Train., 44 (5), 538-557.

Anonymous (2010). Global Recommendations for Physical Activity for Health. WHO. Available at:

https://www.ncbi.nlm.nih.gov/books/NBK305057/ (accessed 10.01.2020)

Anonymous (2015). Physical Activity Fact Sheet $\mathrm{N}^{\circ} 385$, 2015. WHO. Available at: http://www.who.int/mediacentre/factsheets/fs385/en/ (accessed 10.01.2020).

Anonymous (2018). World Health Organisation Fact sheet. Physical activity. WHO. Available at: http://www.who.int/en/news-room/fact-sheets/detail/physical-activity (accessed 10.01.2020).

Aspenes, S. T., Nilsen, T. I., Skaug, E. A., Bertheussen, G. F, Ellingsen, Ø., Vatten, L., Wisløff, U. (2011). Peak oxygen uptake and cardiovascular 
risk factors in 4631 healthy women and men. Med. Sci. Sports Exercise, $\mathbf{4 3}$ (8), 1465-1473.

Azarbal, B., Hayes, S. W., Lewin, H. C., Hachamovitch, R., Cohen, I., Berman, D. S. (2004). The incremental prognostic value of percentage of heart rate reserve achieved over myocardial perfusion single-photon emission computed tomography in the prediction of cardiac death and all-cause mortality: Superiority over $85 \%$ of maximum age-predicted heart rate. $J$. Coll. Cardiol., 44 (2), 423-430.

Beaumont, A., Campbell, A., Grace, F., Sculthorpe, N. (2018). Cardiac response to exercise in normal ageing: What can we learn from masters athletes. Curr. Cardiol. Rev. DOI: 10.2174/1573403X14666180810155513.

Bodegard, J., Erikssen, G., Bjornholt, J. V., Gjesdal, K., Liestøl, K., Erikssen, J. (2014). Reasons for terminating an exercise test provide independent prognostic information: 2014 apparently healthy men followed for 26 years. Eur. Heart J., 26 (14), 1394-1401.

Brugada, J., Benito, B. (2006). Electrocardiographic findings in athletes. E-J. Cardiol. Practice, 4 (31)

Corrado, D., Basso, C., Pavej, A., Michieli, P., Schiavon, M., Thiene, G. (2006). Trends in sudden cardiovascular death in young competitive athletes after implementation of a preparticipation screening program. $J$. Amer. Med. Assoc., 296 (13), 1593-1601.

Degens, H., Stasiulis, A., Skurvydas, A ., Statkevičiene, B. (2019). Physiological comparison between non-athletes, endurance, power and team athletes. Eur. J. Appl. Physiol., 119, 1377-1386.

Dobre, D., Zannad, F., Keteyian, S. J., Stevens, S. R., Rossignol, P., Kitzman, D. W., Landzberg, J., Howlett, J., Kraus, W. E., Ellis, S. E. (2013). Association between resting heart rate, chronotropic index, and long-term outcomes in patients with heart failure receiving $\beta$-blocker therapy: Data from the HF-ACTION trial. Eur. Heart J., 34 (29), 2271-2280.

Ferguson, S., Gledhill, N., Jamnik, V. K., Wiebe, C., Payne, N. (2001). Cardiac performance in endurance-trained and moderately active young women. Med. Sci. Sports Exercise, 33 (7), 1114-1119.
Le, V. V., Wheeler, M. T., Mandic, S., Mandic, S., Dewey, F., Fonda, H., Perez, M., Sungar, G., Garza, D., Ashley, E. A., Matheson, G., Froelicher, V. (2010). Addition of the electrocardiogram to the preparticipation examination of college athletes. Clin. J. Sports Med., 20 (2), 98-105.

Mayolas-Pi, C., Simon-Grima, J., Penarrubia-Lozano, C., MunguíaIzquierdo, D., Moliner-Urdiales, D., Legaz-Arrese, A. (2017). Exercise addiction risk and health in male and female amateur endurance cyclists. $J$. Behav. Addict., 6 (1), 74-83.

Mintale, I., Erglis, A. (2008). Fiziskās slodzes testi, metodoloǵija [Physical exercise tests, methodology]. Latvian Cardiology Society, Rīga, pp. 3-8 (in Latvian).

Mitchell, J. H., Haskell W. L., Raven P. B. (1994). Classification of sports. J. Amer. Coll. Cardiol., 24 (4), 864-866.

Mont, L., Pelliccia, A., Sharma, S. Biffi, A., Borjesson, M., Terradellas, J. B., Carré, F., Guasch, E., Heidbuchel, La Gerche, A. et al. (2016). Preparticipation cardiovascular evaluation for athletic participants to prevent sudden death. EP Europace, 19 (1), 139-163.

Predel, H. G. (2014). Marathon run: Cardiovasculas adaptation and cardiovascular risk. Eur. Heart J., 35 (44), 3091-3098.

Rozenstoka, S., Lace, A., Jubele, K. (2010). Analyses of functional abilities of the body and metabolic processes for participants of public sport and professional sportsmen. In: Res. Articles Med. Pharm. Rīga Stradiņš University, Rīga pp. 170-179.

Skalik, R. (2015). Screening of athletes: An electrocardiogram is not enough. Herz, 40 (3), 386-394.

Utomi V., Oxborough D., Whyte G. P., Somauroo, J., Sharma, S., Shave, R., Atkinson, G., George, K. (2013). Sysytematic review and meta-analysis of training mode, imaging modality and body size influences on the morphology and function of the male athlete's heart. Heart, 99 (23), 1727-1733.

Wheatley, C. M., Snyder, E. M., Johnson, B., Olson, T. P. (2014). Sex differences in cardiovascular function during submaximum exercise in humans. SpringerPlus, 3 (1), 445.

\section{SLODZES, HRONOTROPĀ UN INOTROPĀ KAPACITĀTE SPORTISTIEM AR DAŽĀDU TRENIN̦U REŽİMU}

Fiziskā aktivitāte ir viens no galvenajiem faktoriem, kas nodrošina dažādu neinfekciozo, tai skaitā sirds asinsvadu slimību profilaksi. Būtiska ietekme iedzīvotāju fiziskās aktivitātes ieradumu veicināšanā ir tautas sportam. Pašlaik nav pietiekami zināniski pētīta fiziskās slodzes ietekme uz sportistu amatieru, kuri piedalās sporta sacensībās, organismu, savukārt pētījumi ar profesionālo sportistu vai fiziski pasīvu indivīdu dalību nav atbilstoši. Pētījuma mērkis bija novērtēt slodzes, hronotropo un inotropo kapacitāti sportistiem amatieriem ar dažādu treninu režīmu. Prospektīvā pētījumā tika iesaistīti 600 sportisti amatieri vecumā no 20 līdz 39 gadiem, kuri, atbilstoši Mitchell Sporta veidu klasifikācijai, nodarbojas ar augstas dinamiskas slodzes sporta veidiem. Sportistiem tika noteikti antropometriskie rādìtāji, novērtēts treniņu režīms un veikts maksimālas slodzes kardiopulmonālais tests pēc standartizēta algoritma ar kāpņveida pieaugošu slodzi. Sportistu amatieru slodzes kapacitāte bija atkarīga no treninu režīma, regularitātes un ilguma, bet nebija atkarīga no vecuma. Maksimālās slodzes laikā kardiorespiratorās sistēmas funkcionālie rādītāji un sirds inotropā kapacitāte bija atkarīga no treniṇu režīma. Sirds hronotropā un inotropā kapacitāte, kā arī adaptācija fiziskai slodzei bija augstāka abu dzimumu sportistiem amatieriem nekā netrenētiem indivīdiem. Pētījuma dati liecina, ka sportistiem amatieriem ar treninu programmu 300 minūtes nedēḷā, bija augstākas fiziskās darbaspējas, kuras nodrošina individuāli piemērota treniņu programma, augstāka aerobā un anaerobā kapacitāte. Sportista amatiera veselības stāvoklim un fiziskajām darbaspējām nepiemērots treniņu režīms samazina organisma adaptāciju fiziskai slodzei un palielina pārslodzes un akūta kardiāla notikuma risku. Regulāra padziḷinātā profilaktiskā medicīniskā pārbaude arī sportistiem amatieriem ḷauj objektīvi novērtēt veselības stāvokli, organisma adaptāciju un kardiālo risku, kā arī savlaicīgi veikt izmaiṇas sportista treniṇu režīmā. 